\title{
The assessment of geodiversity - a premise for declaring the geopark Buzăului County (Romania)
}

\author{
Laura Comănescu* and Alexandru Nedelea \\ Department of Geomorphology-Pedology T-Geomatics, Bucharest University, 010041, \\ No. 1, N. Balcescu Avenue, Bucharest, Romania. \\ *Corresponding author.e-mail: lauracomanescu@yahoo.com
}

The geopark Buzăului County does not belong to the Geoparks European Network, as there are numerous governmental, legislative and scientific initiatives in this respect. The geopark is situated in the central-south-eastern part of Romania (in Buzau county) and it has a special potential of geological, geomorphological, biogeographical and anthropic nature, a potential which has to be developed and brought into value. The idea of creating a geopark in this area is relatively recent and it was realized by a series of actions carried on by local authorities in partnership with several institutions, a partnership within which it was accomplished the proposal of a general development framework of the geopark, as well as the launching of a promotion campaign. The scope of this work is to evaluate the geodiversity existing in this space as an important starting point in declaring it as a European geopark, being known that it represents a real "open air museum". The high values of geodiversity and biodiversity represent special strong points in this respect. The method we used was taken from the specialised literature, suffering a series of adjustments to the specifics of the studied area.

In the present format, the method is applied for the first time in the Geography literature, so the values obtained cannot be compared with those obtained by other calculation formulas. Thus, values between 0.20 and 1.91 which resulted cover the entire scale of variables proposed.

\section{Introduction}

The concept of geopark presents multiple valences (Andrăşanu 2008):

- that of representing a territory with a geological heritage of international significance, and an integrated and sustainable management of the respective spaces; spaces which are characterized by a diversity of geosites, geomorphosites and cultural sites;

- this space may be considered as a development territory as there is an integrated management of natural and cultural heritage;
- it represents a guarantee of the quality protection, being obligatory to generate the development of respective space and especially of local communities.

Geopark benefits of its own management measures and it is administered by a structure which is able to protect the sites of any type and contributes to applying some policies of viable regional development. Geopark can be considered as a model for the practical application of concepts and actions which describe geoconservation, namely, identifying of geological, geomorphological and pedological heritage, evaluation of geodiversity, accomplishment of management plans, development of some

Keywords. Geopark; geodiversity; evaluation; Buzăului County; Subcarpathians; Romania. 
actions of geoeducation and promotion of geotourism (Andrăşanu 2008). In Romania, in order to impose the declaring of some geoparks, it is considered that the area which will enter this category complies with all valences previously enumerated; moreover, this represents an element of strengthening the identity of local communities of asserting cultural traditions and of superior development of the existing touristic potential (Andrăşanu 2008).

In the Charta of the European Network of Geoparks (2001 quoted by Andrăşanu 2008) it is considered that "the Geopark must comprise an exact number of geological sites which are important from the scientific point of view, from the point of view of quality, uniqueness, educational potential or with aesthetic value. The sites of interest from the territory of the geopark are mostly geological, but they can also be archaeological, ecological, historical or cultural sites."

Geoparks present a special geodiversity (geological, geomorphological and pedological heritage) (Cendrero 2000), besides an important role being held by biodiversity (biological heritage) and cultural historical diversity (cultural-historical heritage) (figure 1). From the point of geodiversity, it results in a new form of tourism - geotourism, which brings numerous economic benefits for local communities, a form of tourism which is implemented with superior parameters within geoparks (Dowling and Newsome 2006). Within geoparks, natural heritage and cultural inheritance are symbiotically regarded (figure 1). The development of geotourism was accomplished simultaneously with the development of geoparks, and with the

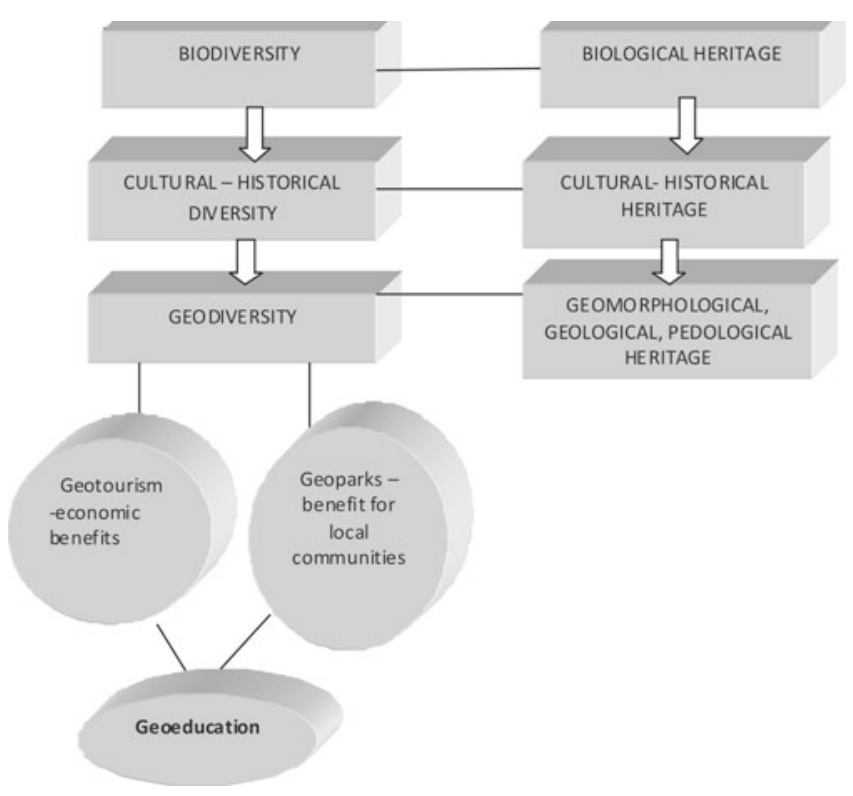

Figure 1. Relationships between geodiversity, geoturism, geoparks and geoeducation. introduction of touristic activity of geosites and geomorphosites (Piacente 2005; Reynard et al. 2009).

The most important stage in the development of geoparks worldwide was in 2004, when UNESCO's initiative regarding UNESCO Global Network of Geoparks took shape. Between 2004 and 2008, numerous geoparks were declared, which led to the globalization of this concept, and to geoparks being received as systemic units, where different development projects can take shape (Andrăşanu 2008; Zouros and Mc Keever 2009; Zouros and Valiakos 2010).

At present, in Europe, 48 areas from 15 countries are accepted in the European Network of Geoparks (www.europeangeoparks.org).

Within Romania's territory, there are several geoparks (in the authorities and present legislation's sense), from among these only the Dinosaurs' Geopark Hategului County is included in the European Network of Geoparks (www. europeangeoparks.org). This was the first park from Eastern Europe which entered the network in 2005. At the legislation level, Romania is one of the few countries which recognize the geopark as an independent protected area.

At the level of local or central authorities, three more geoparks are acknowledged, namely: the Geopark Buzaului County, the Geopark Mehedinti Plateau (which is recognized at Romania's level but not intended for the introduction in the European Network) and the Geopark Anina, the most advanced demarches for introducing in the European network being done for the Geopark Buzaului County. This is the reason why we consider it necessary to know and to advertise it by all means, in order to introduce it within the European network and especially to protect and develop it at superior parameters. The Geopark Buzaului County will be developed following the same model as the Haţeg County Geopark.

The management of the Geopark Buzaului County is based on the strategy of territorial development done and in accordance with UNESCO and the European network Charta of Geoparks' recommendations. In order to ensure the management of the sites of different types within the geopark, three categories of areas are differentiated: strictly protected areas, having the regime of protection of scientific reservations; tampon areas, with a role of protecting previous areas and where there are possible reduced activities of using the resources; areas of sustainable development, where economic activities are done, by different techniques, in the limits of the capacity of resources' regeneration (Andrăşanu 2008).

The most important incorporated value within the space of a geopark is geodiversity. Geodiversity 


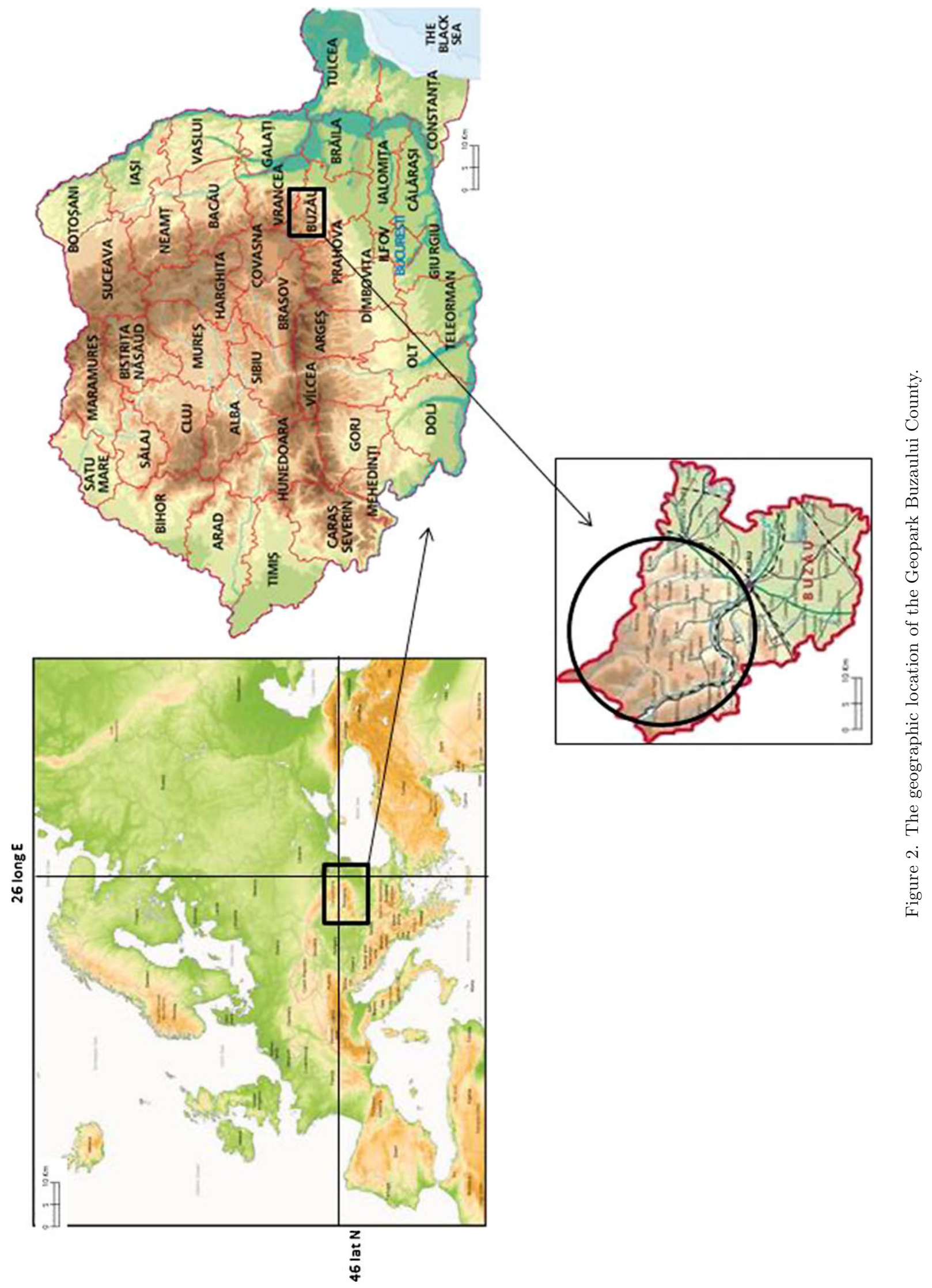


is defined as geological (rocks, minerals, fossils) and geomorphological diversity (relief forms, geomorphic processes) and it also comprises the characteristics of the soil (Gray 2005). The evaluation of geodiversity takes into account values such as intrinsec, cultural, estetic, economic, functional and scientific (Gray 2004). The term of geodiversity was used for the first time in 1991, the theoretic and methodological frame varying a lot from one author to another. Contributions in this field are by Duff (1994), Sharples (1995, 2002), Ibanez (1997), Eberhard (1997), Duran (1998), Alexandrowicz and Kozlowski (1999, 2004), Johansson (1999), Stanley (2001), Nieto (2001), Serano (2002), Zwolinski (2004), Gray (2004, 2005), Gonzales Trueba (2006), Serrano and Ruiz Flano (2007, 2009) (quoted by Serrano and Ruiz Flano 2009).

Thus, Kozlowski (2004) considers that geodiversity was the basis for the increase of biodiversity during the geological history of Earth, at the values included above by Gray (2004), as he also included the components of the hydrosphere (springs, swamps, lakes, rivers). For the author, geodiversity is given by the natural variety of the terrestrial surface, to which other systems resulted from the interaction of natural processes and anthropic activities added.

Nieto's (2001) opinion is less exact, as he considers geodiversity as an integral part of natural diversity, which must be evaluated at local, regional and planetary levels.

\section{Study area}

The possibility of creating a geopark in the area Berca-Meledic was launched in 2005 (Pătroescu et al. 2005) but it was not followed by concrete actions until 2007, when the idea of declaring a geopark in this area was launched by the County Council Buzau. Thus, an active partnership of several institutions was done, envisaging the accomplishment of some interdisciplinary studies (commune's fiches, SWOT analysis, and the proposal of a development framework - the Geopark's Charta, the launching of a promotion campaign) (Andrăşanu 2007a, 2007b, 2008). The geopark is the 7th site on UNESCO's list, its management being done in accordance with this institution's recommendations (http://travelbuzau.com/ proiecte-de-investitii/proiecte-de-dezvoltare-turistica/ geoparcul-tinutul-buzaului).

The Geopark Buzaului County is situated in the central-south eastern part of Romania, in the north of Buzau county, enclosing the south part of Buzaului Mountains (the Curvature Carpathians) and a large part of the Buzaului Subcarpathians (the
Curvature Subcarpathians), at the crossroads of historical paths which connect Muntenia, Transylvania and Moldavia (figure 2). The administrative centre of the geopark is Berca. The geopark consists of 16 municipalities (150 villages), having a surface of 109,826 hectares and a population of 44,510 inhabitants (table 1 ). This proves the existence of a special human potential, a potential which can be attracted in different activities within the geopark (especially tourism-related activities), and activities which could lead to the strengthening of the identity of local communities and to the increase of incomes and implicitly, to the quality of life (Andrăşanu 2007a, 2007b).

The geological characteristics of this space are represented by the geological complexity, varied litological structure, hydrological network mostly transversal, the presence of some intense processes of slopes' modelation favoured by the existence in the north of the geopark of the seismic area Vrancea (figure 3a). From the tectonic point of view, the studied area belongs to the domain of moldavites (the cover of Tarcău, the Subcarpathian cover), lithological and tectonic-structural variety mentioned determining geodiversity (xxx 1967, 1968). In Quaternary, the region was carried into a movement of rise which led to the sinking of the hydrographic network and implicitly to the coming out of some terrace levels (7 levels for Buzau) (Popescu 1970; Ielenicz 1984).

The altitudes vary between 150 metres (at the limit with the plain) and over 1000 metres (at the contact with the mountain) (figure $3 \mathrm{~b}$ ).

Table 1. Administrative-territorial units within the Geopark Buzaului County.

\begin{tabular}{lccc}
\hline Commune & $\begin{array}{c}\text { Surface } \\
\text { (hectares) }\end{array}$ & $\begin{array}{c}\text { No. of } \\
\text { villages }\end{array}$ & $\begin{array}{c}\text { Population } \\
\text { inhabitants) } \\
(2010)\end{array}$ \\
\hline Beceni & 7665 & 9 & 4847 \\
Berca & 7329 & 13 & 9384 \\
Bozioru & 7146 & 10 & 1273 \\
Bisoca & 7268 & 8 & 2933 \\
Brăeşti & 7546 & 7 & 2529 \\
Chiliile & 3566 & 8 & 730 \\
Căneşti & 3102 & 6 & 1029 \\
Colţi & 3492 & 4 & 1274 \\
Cozieni & 5561 & 20 & 2313 \\
Lopătari & 10,332 & 11 & 4343 \\
Mânzăleşti & 9470 & 13 & 2935 \\
Odăile & 3593 & 10 & 1066 \\
Scorţoasa & 9588 & 11 & 3267 \\
Săruleşti & 3365 & 8 & 1510 \\
Valea Salciei & 3230 & 3 & 846 \\
Vintilă Vodă & 6700 & 9 & 3331 \\
\hline
\end{tabular}



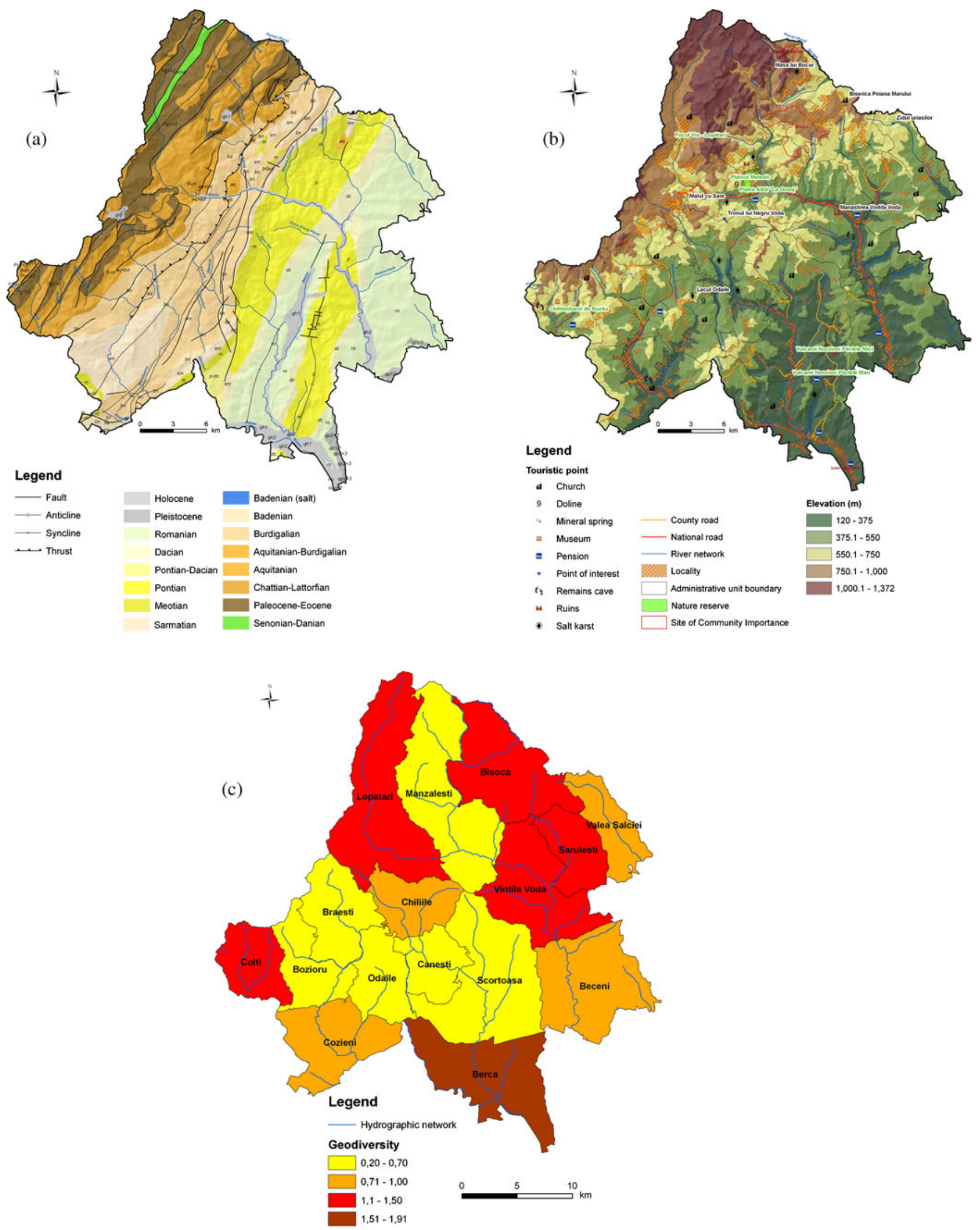

Figure 3. The Geopark Buzaului County. (a) The geological map (after the geological map of Romania, scale 1:200,000, maps Covasna 1968 and Ploieşti 1967), (b) the geotouristic map (after Andrăşanu 2007a, 2007b, modified and completed) and (c) the map of geodiversity (originally). 
Table 2. Value elements from the Geopark Buzaului County (after Andrăşanu 200\%a, 200\%b with additions).

Geodiversity/geological/

geomorphological heritage

Muddy volcanoes Pâclele Mari

Muddy volcanoes Pâclele Mici

The Plateau on salt Meledic with

clints, sinkholes and caves (over 20)

Sinkholes (Meledic, Murătoarea, Odăile)

Relief developed on salt at Lopătari, Mânzăleşti, Bisoca, Sări, Vipereşti, Odăile, Chilii, Căneşti, Berca

The amber from Colţi

Depressions between the landslides where lakes are quartered (Policiori on the Grabicina Valley, Odăila on the Bădila Valley)

The mineral springs from Brăeşti

The active fire from Terca

(Lopătari)

The white rock from Grunj (cineritic abruption)

Erosion witness in sandstone Bucur's table from Bisoca

The giants' wall-erosion witness at Bisoca

Different types of fossils with a value in deciphering the area's evolution
Biodiversity/biological heritage

Invertebrates - Carpathian scorpion

87 species of butterflies

Batrachians (brown frog of earth, salamander, green frog, red frog of mountain)

Reptiles (grey lizard, green lizard, mountain lizard, harmless snakes)

Birds (19 species out of which 3 preserved - Aquila chrysaetos, Corvus corax, Tetrao urogallue)

17 species of mammals

Halofil species (Nitraria schoberi, Artemisia santonicum)

Meadows of steppe type with a relict character

Forest reservations

(Lacurile Forest)
Cultural-historical diversity/heritage

Berca Monastery (XVII century), Mânzăleşti Monastery (XVIII century), Răteşti, Găvanele, Poiana Mărului

Archaeological sites at Berca, Şuchea, Colţi, Scorţoasa

Wooden churches: Brăeşti (XIX century); Coca Antimireşti (XVIII century), Bozioru (XVIII century), Ivăneţu (XIX century), Ruginoasa (XIX century), Bălăneşti (XVIII century),

The rock Piatra Zăganului with rupestral cells

Negru Vodă's chairs - graves in sandstones

The amber museum from Colţi

Rupestral vestiges at Colţi, Cozieni, Vintilă Vodă, Aluniş-Nucu (30), Berca

Church from the XVIII century in Vintilă Vodă, Pâclele from the XVII century, from the XVII century at Băltăgari, Budeşti from the XIX century, Muscelu from the XVII century, Cocârceni from the XIX century, Odăile from the XIX century

Important ethnographic area (traditional architecture, popular celebrations)

Museum collection at Răteşti

The 'manorial mansion' from Răteşti
Morphologically, it can be distinguished as a level of high hills (modelated in Paleogen flysch and Myocene molasses formed by sandstones, clays, tophi, plaster stones or salt), a step of low hills (sandstones, clays, marls, sands and gravels) and a depressionary step (along the main hydrographic corridors, carved in marls and clays). The different geological compositions as form, thickness, age and rocks' properties determined the differentiated modeling of slopes, resulting in varied geomorphological landscapes, which many times led to the emphasis of geosites and geomorphosites.

The northern and north-eastern part of the area overlaps the floor of beech and spruce forests, the central-southern area presents elements of steppe type (Pătroescu 1996). Most part of the territory has got a mosaic aspect, comprising parts of forest, bushes, meadows and arables. Within the geopark there are numerous elements of scientific and touristic interest, elements which are synthetized in table 2 .

\section{Methodology}

The evaluation and mapping of geodiversity based on a proper methodology was accomplished by Serrano and Ruiz Flano (2007), the central idea of which being that geosites and geomorphosites are indicators of geodiversity. 
Below, we propose to calculate the coefficient of geodiversity, and based on this to accomplish the geodiversity map.

The first stage is represented by documentation. General documentation was done from several sources: reference works from the field of geomorphology, geology or tourism; the commune fiches filled in by local administrations and the team which established the Geopark's Charta; statistical data (Statistic Yearbook, PUG) existent and referring to this area; information provided by the locals.

This had in view the establishing of all elements based on which geodiversity was calculated, after a complete inventory was done (geological, geomorphological, hydrological and pedological elements) (figure $3 \mathrm{~b}$ ), the coefficient was calculated based on the formula:

$$
G d=E g / S
$$

(Serrano and Ruiz Flano 2009 in Reynard et al. 2009) where $G d$ is geodiversity, $E g$ is the number of different geological, geomorphological, hydrological and pedological elements and $S$ is the surface we report at.

Unlike the method used in the specialized literature (Serrano and Ruiz Flano 2009 in Reynard et al. 2009 adapted), it was renounced at $R$-coefficent of roughness of the unit, as the analysed space presents the same value of $R$, being a homogenous space from the climatic point of view. The method was applied on administrativeterritorial units, as the plans of management and the projects are accomplished on this category of units, this way the indicator calculated having a special theoretical but more specially a practical value.

\section{Results and discussions}

There were separated (table 3, figure 3c) four classes of geodiversity (0-0.70: low values; $0.70-$ 1.00: medium values, 1.00-1.50: high values and above 1.50: very high values).

For $37 \%$ of the analysed space, geodiversity has got reduced values $(0-0.70)$, the respective areas having generally a lithological homogeneity, smaller declivities, a reduced gamma of present geomorphological processes. In the second class $(0.70-1.00)$, there are $25 \%$ of the territorialadministrative units, which are included on medium declivities, with lithological homogeneity and a few present geomorphological processes (figure 4). The third class (1.00-1.50) comprises $31.25 \%$ of the analysed space, generally situated at lithological or tectonic contacts, with relatively high and numerous declivities and different present
Table 3. Geodiversity values.

\begin{tabular}{lcc}
\hline Municipality & $\begin{array}{c}\text { Surface } \\
(\text { ha) }\end{array}$ & $\begin{array}{c}\text { Geodiversity } \\
\text { value (n/ha) }\end{array}$ \\
\hline Beceni & 7665 & 0.783 \\
Berca & 7329 & 1.91 \\
Bozioru & 7146 & 0.28 \\
Bisoca & 7268 & 1.23 \\
Brăeşti & 7546 & 0.66 \\
Chiliile & 3566 & 0.84 \\
Căneşti & 3102 & 0.64 \\
Colţi & 3492 & 1.17 \\
Cozieni & 5561 & 0.72 \\
Lopătari & 10,332 & 1.35 \\
Mânzăleşti & 9470 & 0.63 \\
Odăile & 3593 & 0.55 \\
Scorţoasa & 9588 & 0.20 \\
Săruleşti & 3365 & 1.18 \\
Valea Salciei & 3230 & 0.83 \\
Vintilă Vodă & 6700 & 1.044 \\
\hline
\end{tabular}

geomorphological processes. The highest geodiversity (over 1.50 ) holds over $6.25 \%$ of the analysed units (1 unit) namely (figure 4) Berca where there are different geosites and geomorphosites and numerous present geomorphological processes. A tight correlation between the localizing of geosites and geomorphosites and the high values of geodiversity can be noticed. By calculating geodiversity for different territorial units done at the same scale and with the same degree of detail, comparisons between them can be done. The evaluation of geodiversity is both a quantity and a quality evaluation, offering important data regarding the natural heritage of the respective spaces.

The method is restrictive as it cannot apply to very limited spaces and this is why a detailed analysis is not allowed. It would be necessary to propose a method which can quantify both intrinsic and extrinsic geodiversity, thus valuable data, with immediate practical ability being obtained.

The map of geodiversity can be correlated to other maps (geosites' map, geomorphosites' map,

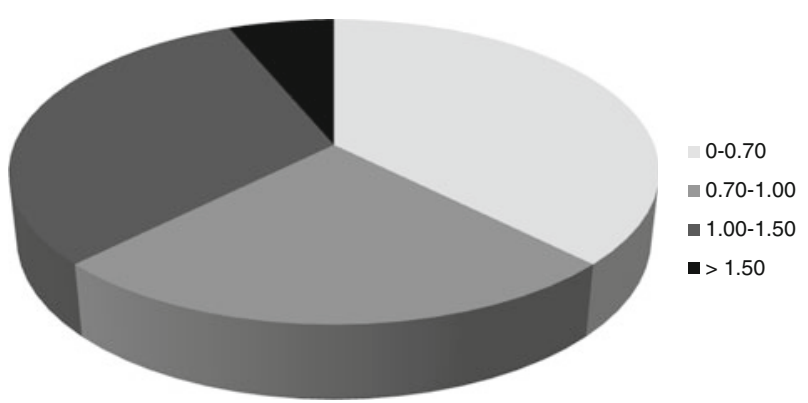

Figure 4. The weight of different classes of geodiversity. 
etc.), and together with the accomplished inventory it can form an important means for the management of the respective geopark.

\section{Conclusions}

Geopark is an important type of protected area (with a different status from one country to another) and it presents clear administrative limits, overlapped with the administrative limits/borders of the included communes and it can represent an engine of sustainable local development and of achieving some future projects (Eder and Patzak 2004).

Geodiversity represents an indicator of geoconservation, as a series of existing theoretic common points - applied and educational. The evaluation of geodiversity imposes as a tool for geoconservation. The relationship between geodiversity and geoconservation must be understood from a double perspective, being the main means by which it can be interpreted in the territorial planning. It can be regarded as the connection between abiotic, biotic elements and the cultural heritage, all these leading to geoconservation and geotourism.

\section{Acknowledgements}

The present contribution is part of the research project PNII/Idei (Inventorying, evaluating and mapping of the geomorphosites. Case studies: the Dobrogea table 1 and and the South Carpathians) financed by NURC (National University Research Council). The authors want to thank their colleague Dr. Viorel Ilinca for his support in accomplishing the graphical part of this article.

\section{References}

Andrăşanu A 2007a Călătorie în ținutul Buzăului - ghid neconvenţional; Accent Print, ISBN 978-973-1772-09-7, $113 p$.

Andrăşanu A 2007b Geoparcul ţinutul Buzăului - direcţii de dezvoltare socio-economică; Propuneri, Centrul Geomedia, Universitatea din Bucureşti, 160p. www.europeangeoparks. org.
Andrăşanu A 2008 Geoconservarea - concepte, metodologie, Aplicaţii - geoconservarea formaţiunilor de vârstă Cretatic Inferior din Bazinul Dâmbovicioara; Teză de doctorat, Universitatea din Bucureşti.

Cendrero A 2000 Patrimonio geológico; diagnóstico, clasificación y valoración; (ed.) En Palacio J, Jornadas sobre Patrimonio geológico y Desarrollo sostenible. Ministerio de Medio Ambiente, Madrid, pp. 23-37. http://travelbuzau. $\mathrm{com} /$ proiectedeinvestitii/proiectededezvoltareturistica/ geoparcultinutulbuzaului

Dowling R K and Newsome D 2006 Geoturism; Elsevier, Oxford, UK.

Eder W and Patzak M 2004 Geoparks - geological attractions: A tool for public education, recreation and sustainable economic development; Episodes 27(3) 162-164.

Gray M 2004 Geodiversity: Valuing and conserving abiotic nature; John Wiley \& Sons Ltd., Chichester, England, p. 434.

Gray M 2005 Geodiversity and geoconservation: What, why and how?; In: Geodiversity \& Geoconservation (ed.) Santucci V L, The George Wright Forum 22(3) 4-12.

Ielenicz M 1984 Munţii Ciucaş-Buzău; Studiu de geomorfologie. Edit. Academiei, Bucureşti, Romania, p. 165.

Kozlowski S 2004 Geodiversity. The concept and scope of geodiversity; Polish Geol. Rev. 52 833-839.

Nieto L M 2001 Geodiversidad: Propuesta de una definicion integradora; Boletin Geologico y Minero 112 3-12.

Pătroescu M 1996 Subcarpații dintre Râmnicu Sărat și Buzău - Potenţial ecologic şi exploatare biologică; Edit. Carro, Bucureşti, Romania, p. 125.

Pătroescu M, Grigorescu D, Andrăşanu A and Fodolică V 2005 Geoparcul Berca-Meledic din Subcarpaţii Buzăului o necesitate în valorificarea patrimoniului natural şi etnocultural; Proceedings Sesiunea anuală de Comunicări Ştiinţifice a Facultăţii de Geografie, Universitatea Bucureşti.

Popescu D 1970 Observaţii geomorfologice preliminare asupra teraselor din Subcarpaţii cuprinşi între valea Buzăului şi valea Slănicului de Buzău; $A U B$-Geogr. XIX 87-96.

Piacente S 2005 Geosites and geodiversity for a cultural approach to Geology; Il Quaternario 18(1) 11-14.

Reynard E, Coratza P and Regolini-Bissig G 2009 Geomorphosites; Verlag Friedrich Pfeil, Munchen, 240p.

Serrano E and Ruiz Flano P 2007 Geodiversity. A theoretical and applied concept; Geographica Helvetica 62(4) 140147.

Zouros N and Mc Keever P 2009 European Geoparks: Tools for heritage protection and sustainable development; In: European Geoparks, Natural Hystory Museum of Lesvos, pp. $15-20$.

Zouros N and Valiakos I 2010 Geoparks management and assessment; Bull. Geol. Soc. Greece XLIII(nr.2) 965-975.

xxx 1967 Harta geologică - foaia Ploieşti, scara 1: 200,000. Institutul Geologic al României.

xxx 1968 Harta geologică - foia Covasna, scara 1: 200,000. Institutul Geologic al României. 